\title{
Impact of Changing the Surrounding Urban Context on Sustainable Design of Historic Buildings
}

\author{
Hafedh Abed Yahya ${ }^{1, a^{*}}$, Khalid J. Aluddin Ismail ${ }^{1, b}$ and Turki Hasan Ali ${ }^{2, \mathrm{c}}$ \\ ${ }^{1}$ University of Mosul, Almajmoa Althaqafia, Mosul 41001, Iraq \\ ${ }^{2}$ University of Nowroze, Tenahi, Duhok 42001, Iraq

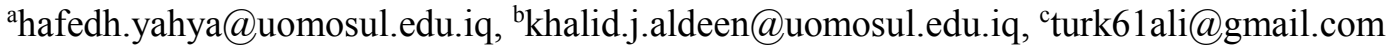

\begin{abstract}
Research aims are to explain the impact of the built environment on the efficiency of sustainability of historical buildings. The most vital factor of sustainability in hot and semi-dry climates is the thermal efficiency of inner spaces. The conventional building materials used in historic buildings in Mosul have high thermal efficiency, but it works with the surrounding built environment as an integrated thermal system. This surrounding built environment could be exposed to dramatic changes within the efforts of reconstruction of Mosul city. Al-Aghawat mosque was selected as a case study due to its surrounding urban context and original conventional building materials. This research adopts ENVImet analysis method. Physiologically Equivalent Temperature (PET) index was assumed to be the indicator for thermal comfort in hot and semi-dry weather. ENVI-met program applied for simulation of two cases at the hottest day in the summer of 2019-2020 through climatic data. The first case estimates the air temperature in the inner and open spaces of the mosque with its original surrounding context and then checks the air temperature of the same spaces after removing the surrounding context. The results reveal changes in thermal efficiency within the two cases. In order to conserve the thermal efficiency of the historic buildings, the researchers recommended adopting a conservation strategy of the surrounding context.
\end{abstract}

Keywords: Building materials; built environment; thermal comfort, ENVImet; Al-Aghawat mosque.

\section{Introduction}

The term historic building is a cumulative experience that indicates the earliest eras' social, economic, and cultural outcomes. While urban communities need to fulfill the evolving states of daily life and urban prerequisites as each experiencing human nature on the first side, they go through urban improvement measures to ensure the qualities identifying the city character and environment side [1]. Modern society, having perceived the particularity of heritage resources corresponding to their cultural and physical context and the embodiment of authenticity in imaginative variety, has given another concentration for the issue of universal significance [2]. In cases of the surrounding context in historic fabric exposed to severe damages or destructions, the policymakers and planners tend to remove the frayed fabric. Part of the causes of such action is to deal with the historical building as monumental features. The research aims are to explore the impact of removing the surrounding context on the sustainability of monumental historic building

\section{Sustainable Design of Historic Buildings}

Thermal Comfort. Climate is a significant design component that serves to accomplish sustainability through giving the ideal microclimate encourages social cooperation in spaces. Achieving a decent climate is one of the design principles regarded for human concerning who feel great to stroll through, lay down, play, stand, speak, study, or simply unwind and mull over [3], and not presented to wind, rain, heat, traffic, noise or pollution. Thermal comfort is a fundamental variable that ought to be investigated in any space design that may usefully affect the conduct parts of individuals utilizing these spaces [4]. Thermal environment components are classified into three groups; Thermal comfort, in which individuals feel neither too blistering nor excessively cold and don't see the temperature to be an issue [5]. Thermal stress, where the thermal environment will cause obvious medical conditions, 
could severely damage human health. And Thermal discomfort, where is the zone between the initial two. However, humans may suffer excessively hot or excessively cold but don't show clinical indications of past touchiness and weakness. International Standard ISO 7730 characterized human thermal comfort as "that condition of mind in which satisfaction is expressed with the thermal environment" [6]. All six variables influencing thermal comfort are natural and individual. The variables might be free of one another, yet all add to human thermal comfort.

- Environmental factors: Humidity, Air velocity, Radiant temperature, and Air temperature.

- Personal factors: Metabolic Heat and Clothing Insulation.

The countless numeral of thermal indices available may be characterized in two gatherings: experimental or logical. The previous branch depends on estimations with subjects or on connections that don't follow the hypothesis [7, 8]. Rational lists are later advanced by the late improvement of figuring procedures and depend on the people power equilibrium. As example, Heat Stress Index (HIS), Index of Thermal Stress (ITS), Physiological Equivalent Temperature (PET), Predicted Mean vote perceived temperature (PMV), etc. [9]. Thermal comfort is defined by (PET) index that will be adopted in this research paper.

Using of PET index to evaluate thermal comfort. The utilization of explicit models for the exact estimation of (PET) is required for thermal sensation evaluation. Obviously, there are other records, yet PET index is further reasonable because it was adjusted to exterior and interior settings [10], its wide circulation, and the utilization of $\left({ }^{\circ} \mathrm{C}\right)$ unit in order to express thermal comfort, which makes the outcomes understandable for possible users. PET depends on the heat equilibrium of the human [11], including all heat measures steps within the individual body and the surroundings. PET "expressed by the air temperature at which the same skin temperature balances the human energy budget for the assumed indoor conditions and sweat rate as under the actual complex outdoor conditions to be assessed" [10]. The meteoric input variables are vapor pressure, wind speed, air temperature, and mean radiant temperature. PET likewise counts the warmth move opposition of attire and inside heat creation.

Historical Background. The Mosque of Al-Aghawat is one of Iraq's historical mosques. It dates back to $1114 \mathrm{AH} / \mathrm{AD} 1702$ and is located in the old Mosul city, surrounded by some old buildings (grand bazaar and shops). The nearest point is the iron bridge. This mosque was built of traditional stone, while the plaster was used as abounding material. The minaret finished with decorative clay brick [12]. This mosque is one of the heritage mosques, was built by Khalil Agha, Ibrahim Agha, and Ismael Agha. They are the sons of Abdul Jalil Agha, who was the prince of the Jalili family. The area of the mosque is $2500 \mathrm{~m}^{2}$. As shown in Fig. 1, small chapel surrounded by eight other large domes in the form of rooms are supplements to the Great Mosque and consists of the chapel of three sections, and the Mihrab (niche) in the chapel is the most beautiful of niches, which built-in Mosul after the year of the millennium of migration. It consists of two cylindrical elements, on them the arch of the façade of the Mihrab, the minbar (platform), one of the nicest platforms in the city of Mosul, is rich in marble motifs, and the minaret is built of bricks and is located west of the chapel [13].

History is alive in Mosul: there are many archaeological remnants tracing back to Assyrian times [15]. Mosul contains numerous antiquated structures from the thirteenth century. These incorporate Al-Nori Mosque, with the inclining minaret, Al-Mujahidi Mosque, Nabi Jerjis Mosque, a few Christian Churches, and different Muslim altars and catacombs. On $14^{\text {th }}$ June 2014, Mosul turned into the biggest city to tumble to ISIS [16]. Through the liberation of the city from ISIS, which was led by Iraqi and coalition forces, the old city of Mosul was exposed to severe damage. Fig. 2 shows the destruction of Al-Aghawat and its surrounding context after 2017. 


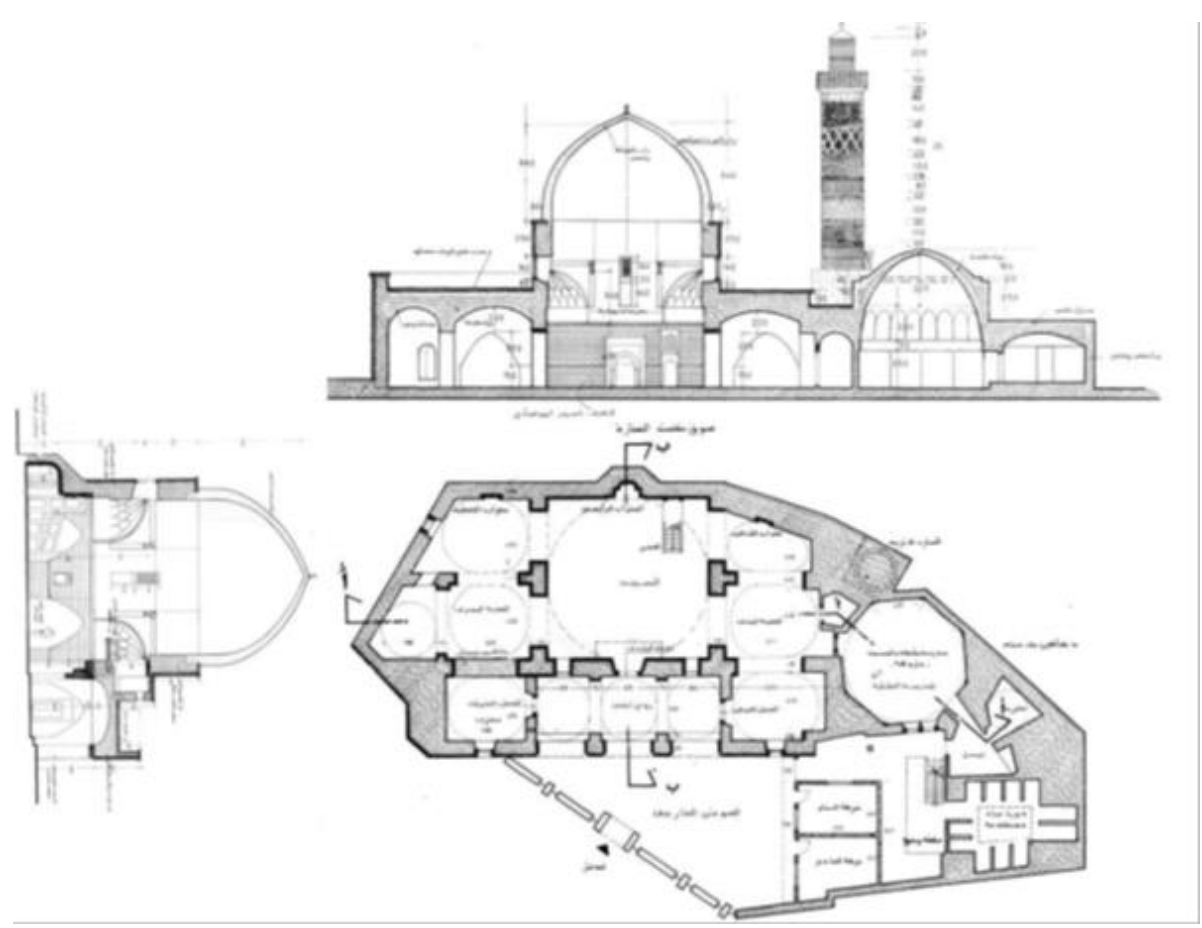

Figure 1. Plan and sections of Al-Aghawat mosque [14].

(a)
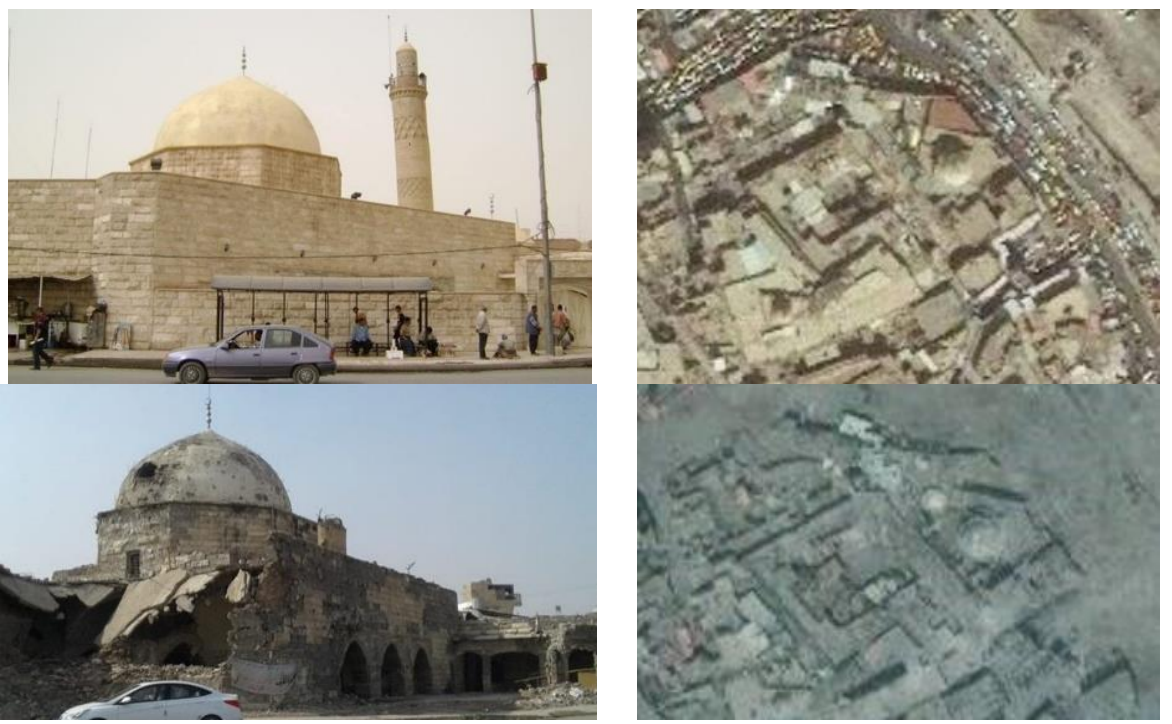

Figure 2. The surrounding of Al-Aghawat mosque (a) before 2014; (b) after 2017.

Methods and Data. The microclimate is unequivocally exposed with impacts of design elements like space organization, building materials, and architectural elements like move wind patterns and control solar radiation. The main problem of the research focuses on the existing structure of the surrounding urban context to explore these effects on human thermal comfort. Mosul was chosen as a model city of semi-sweltering dry environment region of the northern area of Iraq. Mosul is situated at $\left(36.34^{\circ} \mathrm{N}\right.$ $43.13^{\circ} \mathrm{E}$ ), located under a semi-hot-dry climate with a hot-dry summer and a distinct cold rainy winter [17]. The hottest days in Mosul fall in July as a rule (highest value $=48{ }^{\circ} \mathrm{C}$ ), the lowest temperature dry bulb mainly lays in January (minimum value $=0^{\circ} \mathrm{C}$ ), Table 1 . The hottest day is on $\left(13^{\text {th }} \mathrm{July}\right.$ 2020) in Mosul needed for simulations that were chosen in the hottest day all of the year, Table 2 [18].

Table 1. Mosul temperatures for each month between (2015-2020) [18].

\begin{tabular}{|c|c|c|c|c|c|c|c|c|c|c|c|c|}
\hline Temperature & Jan. & Feb. & Marc. & Apr. & May & Jun. & Jul. & Aug. & Sept. & Oct. & Nov. & Dec. \\
\hline Daytime Temperature & $15^{\circ} \mathrm{C}$ & $18^{\circ} \mathrm{C}$ & $22^{\circ} \mathrm{C}$ & $28^{\circ} \mathrm{C}$ & $34^{\circ} \mathrm{C}$ & $41^{\circ} \mathrm{C}$ & $48^{\circ} \mathrm{C}$ & $46^{\circ} \mathrm{C}$ & $42^{\circ} \mathrm{C}$ & $31^{\circ} \mathrm{C}$ & $23^{\circ} \mathrm{C}$ & $18^{\circ} \mathrm{C}$ \\
\hline Night-time Temperature & $0^{\circ} \mathrm{C}$ & $1{ }^{\circ} \mathrm{C}$ & $5^{\circ} \mathrm{C}$ & $8^{\circ} \mathrm{C}$ & $15^{\circ} \mathrm{C}$ & $21^{\circ} \mathrm{C}$ & $23^{\circ} \mathrm{C}$ & $21^{\circ} \mathrm{C}$ & $17^{\circ} \mathrm{C}$ & $10^{\circ} \mathrm{C}$ & $2^{\circ} \mathrm{C}$ & $0^{\circ} \mathrm{C}$ \\
\hline
\end{tabular}


Table 2. Mosul weather in $13^{\text {th }}$ July 2020 [18].

\begin{tabular}{|c|c|c|c|c|c|c|}
\hline Time & Temp $\left({ }^{\circ} \mathbf{C}\right)$ & Wind $(\mathbf{k m} / \mathbf{h})$ & Gust $(\mathbf{k m} / \mathbf{h})$ & Humidity & Cloud & Pressure (mb) \\
\hline 00.00 & 30 & 13 from E & 28 & $29 \%$ & $5 \%$ & 998 \\
\hline 03.00 & 28 & 11 from ENE & 23 & $30 \%$ & $3 \%$ & 997 \\
\hline 06.00 & 30 & 8 from NE & 14 & $29 \%$ & $0 \%$ & 998 \\
\hline 09.00 & 37 & 5 from ENE & 6 & $20 \%$ & $0 \%$ & 998 \\
\hline 12.00 & 41 & 5 from WSW & 6 & $15 \%$ & $2 \%$ & 997 \\
\hline 15.00 & 42 & 19 from SW & 22 & $11 \%$ & $0 \%$ & 996 \\
\hline 18.00 & 38 & 21 from NE & 24 & $17 \%$ & $0 \%$ & 996 \\
\hline 21.00 & 34 & 15 from E & 32 & $26 \%$ & $0 \%$ & 997 \\
\hline
\end{tabular}

The research uses ENVI-met to reenact the compositional model of examination as an intuitive framework comprising of many powerful subsystems going from air elements, over material reaction down to building indoor environment. All frameworks are determined in one significant model, such as a metropolitan quarter, permitting them to cooperate and receive a genuine ecological framework. The ENVI-met framework will give high-goal information to any of these segments. ENVI-met is a 3-dimensional microclimate model intended to reenact the face air associations in the metropolitan climate with a normal goal down to $0.5 \mathrm{~m}$ in space and 1-5 sec on schedule. Ordinary zones of utilization are architecture, landscape architecture, environmental planning, or building design as examples [19]. Air temperature is dictated by the various source and sinks of reasonable heat and vapor inside the model domain. Because of the determined three-dimensional wind field, a shift in weather conditions and dissemination noticeable all around is simulated.

The ground surface and vegetation leaves go about as sources or sinks for both temperature and stickiness in the climate model. Building walls and rooftops mainly act as surfaces interchanging heat with the atmosphere, yet can likewise go about as humidity sources if elevations or rooftop greening is applied [19]. In order to assess the impact of the surrounding built context, Alaghawat mosque was selected as a case study due to the exposure to damages and surrounding fabric within the military attack to liberate Mosul from ISIL. Types of traditional building materials used in Al-aghawat mosque were implemented like daub stone, plaster, and local marble located in a commercial area [20]. By using ENVI-met analysis model of architecture, we can estimate the air temperature in two cases: Firstly, the Mosque of Al-Aghawat within its original traditional context (see Figure 3) and Secondly, Mosque without its original context (see Figure 4).

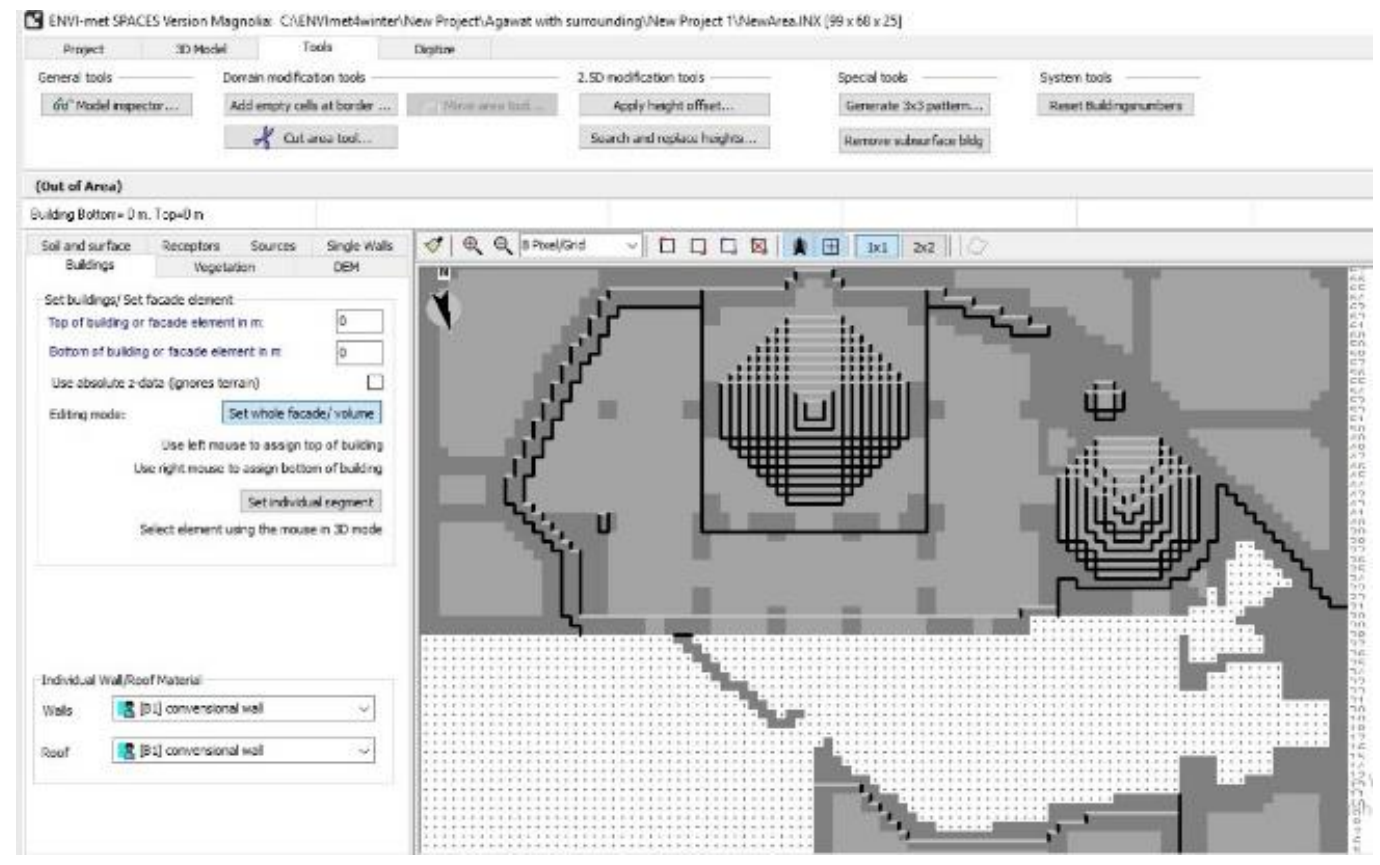

Figure 3. Al-Aghawat mosque model within its original traditional context. 


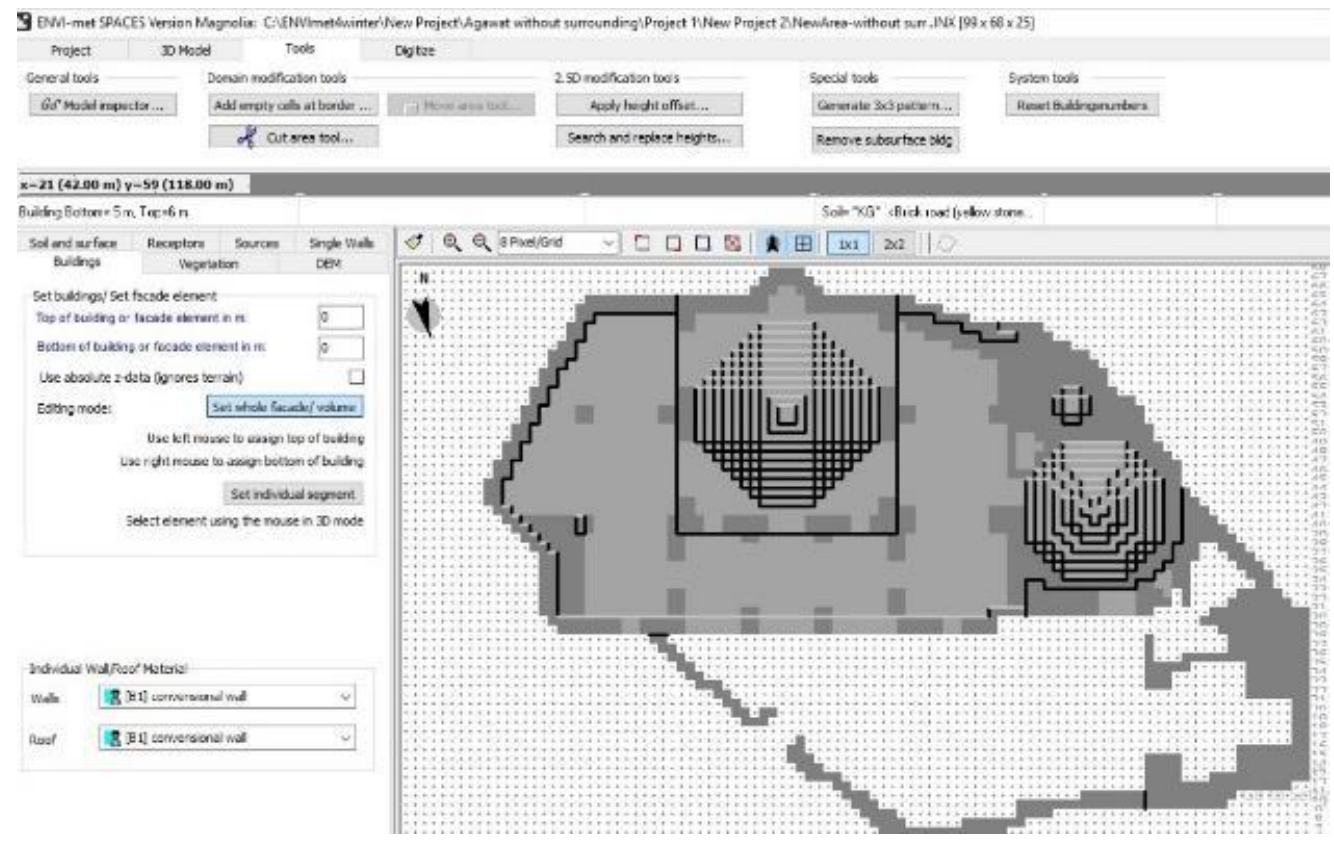

Figure 4. Al-Aghawat mosque model without its original traditional context.

\section{Results and Discussion}

Figure 5 shows thermal comfort index (PET) maps of Al-Aghawat mosque model within its original traditional urban context. The simulation was conducted on the hottest day in summer at midday of $13^{\text {th }}$ July 2020 . It shows that the inner spaces in the prayer hall were within a human comfort zone, and the air temperature between $22.48-23.80^{\circ} \mathrm{C}$, while PET in the open spaces like the courtyard and the entrance varied from low to high values referring that it was out of the human comfort zone and the air temperature increased from $21.17-30.39^{\circ} \mathrm{C}$. Air temperature in semi-closed spaces like arcades and covered walkways was $23.8-25.12^{\circ} \mathrm{C}$.
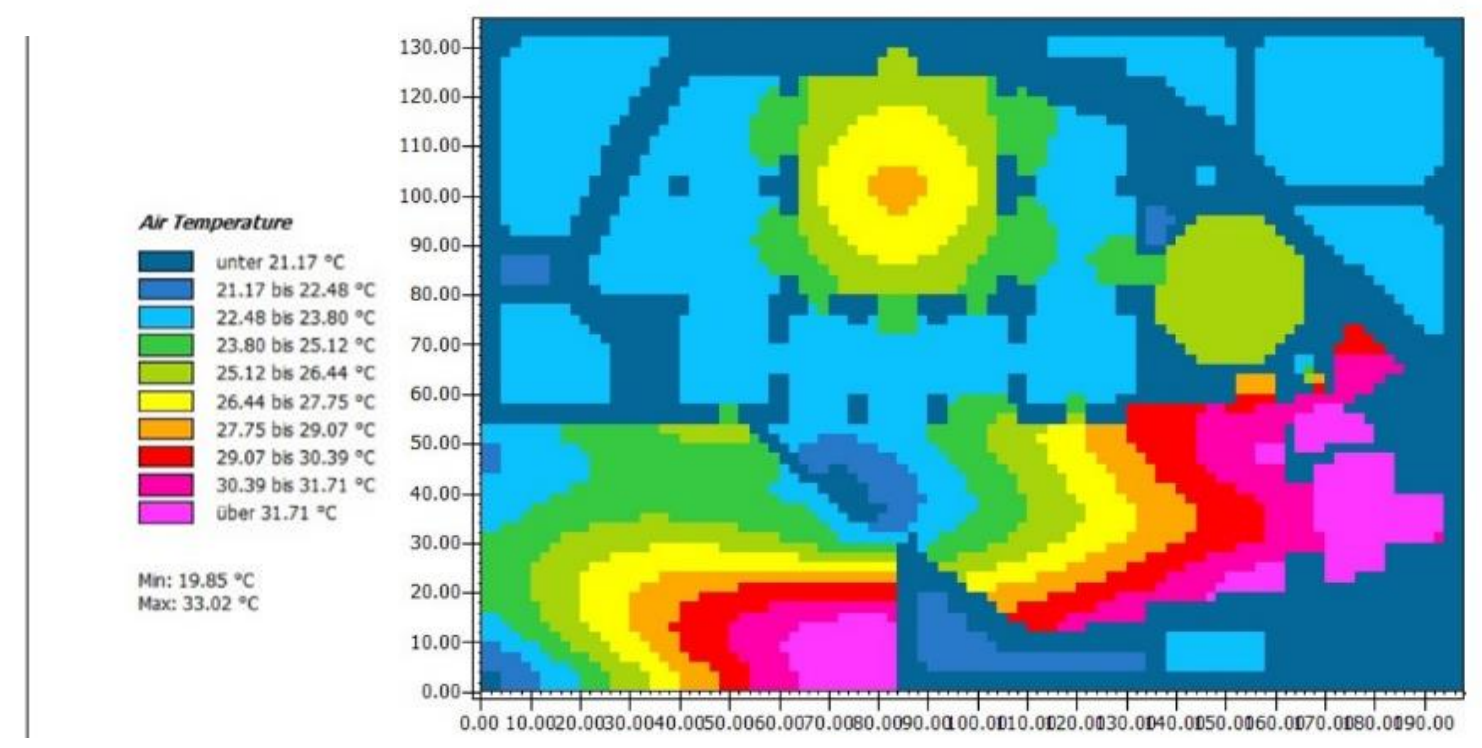

Figure 5. PET maps of Al-Aghawat mosque model within the surrounding traditional urban context.

Figure 6 shows thermal comfort index (PET) maps of Al-Aghawat mosque model without its original traditional surrounding context. The simulation was conducted on $13^{\text {th }}$ July 2020 , the hottest day in summer at mid-day with the same condition as the first case. It shows that the inner spaces in the prayer hall exceeded the human comfort zone and the air temperature between $30.39-31.71{ }^{\circ} \mathrm{C}$ and its look like the same with open spaces like the courtyard and the entrance referring to it out of 
the human comfort zone. This result is logical due to these open spaces located at the North side of the prayer hall, so they in a shading area, while the prayer hall located on the south side and exposed to direct sun radiation at the appointed time for simulation.

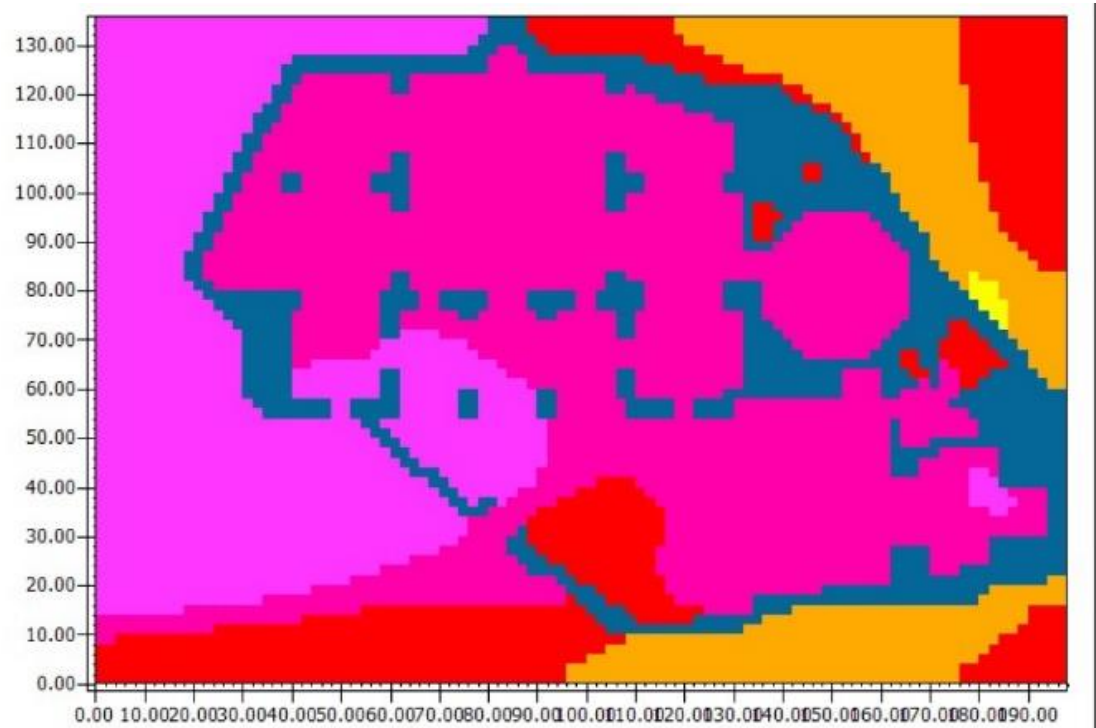

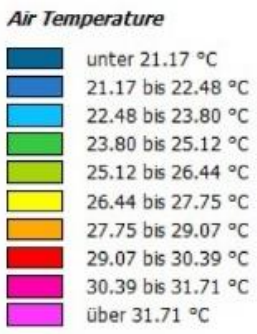

Min: $19.85^{\circ} \mathrm{C}$ $\operatorname{Max}: 33.02{ }^{\circ} \mathrm{C}$

Figure 6. PET maps of Al-Aghawat mosque model without surrounding traditional urban context.

The factor interprets the variance in thermal comfort and microclimatic between two cases. The surrounding urban context of the buildings defines the relations of shaded spaces, so different parts haven't assumed successful parts where structures were only a detached unsupported structure coasting at unbounded space.

\section{Conclusions}

The study shed discussed a relationship between the building and the surrounding urban context and its effect can affect users' thermal comfort in the built environment.

- The thought of examining users' thermal comfort in the interior and exterior spaces joins the point of raising regard for accessible techniques and instruments that encourage planning and assessing electives before making a move in execution.

- Mean radiant temperature was fundamental variable impacting users' thermal comfort, so shading of surrounding urban context is considered the best system to accomplish this objective.

- Arcades and covered walkways, pergolas will enhance the environmental conditions and participate in better human comfort conditions.

- Closed and semi-shut open spaces ought to be received in a warm environment to make a controlled microclimate.

\section{References}

[1] Ulusoya, M., Erdogan, E., Erdogan, H.A. and Orala, M., 2013. Re-using of the historical buildings in the context of sustainablity: An architectural design studio study on Old Girls Teacher Training School. International Archives of the Photogrammetry, Remote Sensing and Spatial Information Sciences, 5, p.W2.

[2] Orbaşli, A., 2017. Conservation theory in the twenty-first century: slow evolution or a paradigm shift?. Journal of Architectural Conservation, 23(3), pp.157-170.

[3] Ramadan, M.F.A., 2010. Interactive urban form design of local climate scale in hot semi-arid zone. Doctoral dissertation, University of Sheffield. 
[4] Setaih, K., Hamza, N., Mohammed, M. A., Dudek, S., and Townshend, T., 2014. CFD modeling as a tool for assessing outdoor thermal comfort conditions in urban settings in hot arid climates. Journal of Information Technology in Construction, 19(2014), pp. 248-269.

[5] Ali, T.H., 2016. Human Thermal Comfort Evaluation in Open Spaces of Two Multi-Story Residential Complexes Having Different Design Settings, Duhok-Iraq. Engineering and Technology Journal, 34(8 Part (A) Engineering).

[6] Liu, W., Lian, Z. and Liu, Y., 2008. Heart rate variability at different thermal comfort levels. European journal of applied physiology, 103(3), pp.361-366.

[7] Mohan, M., Gupta, A. and Bhati, S., 2013. A modified approach to analyze thermal comfort classification. Atmospheric and Climate Sciences, 2014.

[8] Kenawy, I. M., Afifi, M. M. and Mahmoud, A. H., 2010, November. The effect of planting design on thermal comfort in outdoor spaces. In Proceedings of the First International Conference on Sustainability and the Future, Egypt, Cairo (pp. 23-25).

[9] Toudert, F.A., 2005. Dependence of outdoor thermal comfort on street design in hot and dry climate. Ph.D. Thesis, Berichte des Meteorologischen Institutes der Universität Freiburg.

[10] Höppe, P., 1999. The physiological equivalent temperature-a universal index for the biometeorological assessment of the thermal environment. International Journal of Biometeorology, 43(2), pp.71-75.

[11] Höppe, P., 2002. Different aspects of assessing indoor and outdoor thermal comfort. Energy and Buildings, 34(6), pp.661-665.

[12] Yahya, H. A. and Abdul Samad, M. H., 2019. Demonstration of building materials utilization in traditional mosque. International Conference on Humanities, Art and Philosophies (ICHAP), Malaysia, pp. 1-11.

[13] Daywahji, S. 1963. Jawami Al-Mawșil Fi Mukhtalif Al-Usur. Makṭbaat Shafĩq, Baghdad. (In Arabic).

[14] Dhanoon, Y., Malla Shareef, and Alsaigh, A., 1983. Al-Amaer Al-Denia fi Madenat Al-Mosul. General Authority for Antiquities and Heritage, Iraq. (In Arabic).

[15] Dabrowska, K. and Hann, G., 2008. Iraq then and now: A guide to the country and its people. Bradt Travel Guides..

[16] The Editors of Encyclopedia Britannica, Mosul, 2014. https://www.britannica.com/place/Mosul.

[17] Yousif, K.M., 2012, May. Control of solar heat gain to reduce the energy consumption of buildings in Iraq. In Proceedings of the World Renewable Energy Forum, Denver, CO, USA (pp. 13-17).

[18] World Weather online, 2020. Available: https://www.worldweatheronline.com/mosul-weather history/ninawa/iq.aspx

[19] ENVI_MET Decoding Urban Nature, 2020. Available: https://www.envi-met.com/

[20] Yahya, H.A., 2015. Environmental Impact of Predominant Building Materials of Mosques in Mosul, Iraq from 1100s to 1800s Ad (Doctoral dissertation, Universiti Sains Malaysia). 